Research Article

\title{
Association between osteoprotegerin gene polymorphisms and cardiovascular disease in type 2 diabetic patients
}

\author{
Changlei Guo, Fudong Hu, Shaoli Zhang, Yakun Wang and Hengdao Liu \\ Department of Internal Medicine, The First Affiliated Hospital of Xinxiang Medical University, \\ Weihui, Henan Province, P.R. China.
}

\begin{abstract}
Osteoprotegerin (OPG) gene polymorphisms (T245G, T950C and G1181C) have been associated with osteoporosis and early predictors of cardiovascular disease. The aim of this study was to evaluate whether these polymorphisms contribute to cardiovascular disease (CVD) in type 2 diabetic patients. We performed a case-control study with 178 CVD subjects with diabetes and 312 diabetic patients without CVD to assess the impact of variants of the OPG gene on the risk of CVD. The OPG gene polymorphisms were analyzed by using the polymerase chain reaction (PCR) and restriction fragment length polymorphism (RFLP). There was no significant association between the T245G and G1181C polymorphisms and CVD in the additive genetic model (OR =0.96, 95\% Cl 0.64-1.45, $p=0.79 ; O R=1.06$, $95 \% \mathrm{Cl} 0.81-1.39, \mathrm{p}=0.65$, respectively). However, the $\mathrm{C}$ allele of the T950C polymorphism was independently associated with a risk of CVD in type 2 diabetic patients in this genetic model $(O R=1.38,95 \% \mathrm{Cl} 1.07-1.80, p=0.01)$. This study provides evidence that the $\mathrm{C}$ allele of the T950C polymorphism is associated with increased risk of CVD in diabetic patients. However, well-designed prospective studies with a larger sample size are needed to validate these results.
\end{abstract}

Keywords: cardiovascular disease, osteoprotegerin, polymorphism.

Received: January 11, 2013; Accepted: March 20, 2013.

\section{Introduction}

Mortality due to cardiovascular disease (CVD) has declined worldwide during the past few decades (Wijeysundera et al., 2010). However, during the same time period, the number of CVD deaths attributable to diabetes has increased (Puri et al., 2012). Certain factors need to be considered when explaining these divergent trends. First, although the prevalence of other risk factors, such as smoking, hypertension and hypercholesterolemia, has been reduced by prevention programs, the incidence of diabetes has been steadily rising (Chen et al., 2011). Second, there has been no significant decline in the increased cardiovascular risk experienced by diabetic subjects. Clearly, there is an urgent need to curb the current epidemic of diabetes and to prevent CVD in diabetics. Although little is known about the factors underlying the increased cardiovascular risk in diabetic patients, studies in diabetic and nondiabetic subjects suggest that the risk of CVD is influenced by genetic factors (Lusis et al., 2004).

Osteoprotegerin $(O P G)$, also known as osteoclastogenesis inhibitory factor, is a member of the tumor necrosis

Send correspondence to Changlei Guo. Department of Internal Medicine, The First Affiliated Hospital of Xinxiang Medical University, 88 Jiankang Road, Weihui City 453100, Henan Province, P.R. China. E-mail: guodaniel@163.com. factor receptor superfamily of cytokines (Simonet et al., 1997). Clinically, $O P G$ may play a role in the development of osteoporosis, inflammatory bone diseases, multiple myeloma and malignant bone resorption (Goranova-Marinova et al., 2007; Turk et al., 2009). In addition, $O P G$ has been associated with the presence and severity of cardiovascular events: elevated serum $O P G$ concentrations have been found to correlate with the severity of peripheral artery disease and heart failure, symptomatic carotid stenosis, unstable angina, vulnerable carotid plaques and acute myocardial infarction (Golledge et al., 2004; Crisafulli et al., 2005; Ueland et al., 2005; Ziegler et al., 2005; Sandberg et al., 2006; Kadoglou et al., 2008; Song et al., 2012).

The gene encoding $O P G$ is affected by common, functionally important genetic polymorphisms that have been associated with osteoporosis and neuroarthropathy and are considered early predictors of cardiovascular disease (Collin-Osdoby, 2004; Soufi et al., 2004; Styrkarsdottir et al., 2008; Pitocco et al., 2009). Some recent studies have shown that the T245G, T950C and G1181C polymorphisms of the $O P G$ gene are associated with the vulnerability of carotid plaques and risk of stroke (Straface et al., 2011; Biscetti et al., 2012).

However, the extent to which these genetic markers predispose to increased cardiovascular complications in type 2 diabetes remains uncertain. The purpose of the pres- 
ent case-control study was therefore to determine whether the T245G (rs3134069), T950C (rs2073617) and G1181C (rs2073618) polymorphisms of the $O P G$ gene play a role in CVD in type 2 diabetic patients.

\section{Materials and Methods}

\section{Study population}

All participants were randomly recruited from the Department of Internal Medicine of The First Affiliated Hospital of Xinxiang Medical University in Weihui (Henan Province, People's Republic of China), from September 12, 2007 , to July 20, 2012. Type 2 diabetes was diagnosed according to WHO criteria (Alberti and Zimmet, 1998). Age at diagnosis of type 2 diabetes was $>40$ years in $98 \%$ of the subjects and the minimum age at onset was 37 years. Type 1 diabetes was carefully excluded on clinical grounds based on a review of medical records, on the fasting C-peptide levels and on the absence of islet-related auto-antibodies. For the purpose of this study, CVD was defined as the occurrence of a fatal or nonfatal myocardial infarction or coronary artery bypass grafting. Subjects diagnosed with CVD before the diagnosis of type 2 diabetes were excluded, as were those diagnosed with stroke and/or angina. After these exclusions, 181 women (117 CVD case subjects and 64 control subjects) and 309 men (195 CVD case subjects and 114 control subjects) were enrolled in the study. Hypertension was diagnosed as a systolic blood pressure (SBP) $\geq 140 \mathrm{mmHg}$ and/or a diastolic blood pressure (DBP) $\geq 90 \mathrm{mmHg}$, or the current use of antihypertensive medication. Hypercholesterolemia was diagnosed as total cholesterol $\geq 5.2 \mathrm{mmol} / \mathrm{L}$, and $/$ or triglyceride $\geq 1.7 \mathrm{mmol} / \mathrm{L}$ and/or low density lipoprotein cholesterin $\geq 3.1 \mathrm{mmol} / \mathrm{L}$. $\mathrm{HbA} 1 \mathrm{c}$ was measured on the same day that the samples were taken using a standard assay and a Bio-Rad Variant HPLC II system (Bio-Rad Laboratories, Hemel Hempstead, UK), in accordance with the Diabetes Control and Complication Trial recommendations (Mitka, 2009).

All subjects were of Han Chinese origin from central China and belonged to independent pedigrees. Informed consent was obtained from all participants and the study was approved by the institutional review board of Xinxiang Hospital. Experiments were done according to the principles expressed in the Declaration of Helsinki.

\section{Single nucleotide polymorphism genotyping}

DNA was extracted from peripheral blood by standard procedures and screened for the $O P G$ gene polymorphisms T950C, T245G and G1181C using the polymerase chain reaction (PCR) and restriction fragment length polymorphism (RFLP), as previously described (Soufi et al., 2004; Pitocco et al., 2009; Biscetti et al., 2012). A 570-bp fragment around the T950C polymorphism was amplified with the primer pairs: 5'- TGCGTCCGGATCTTGGCTG GATCGG-3' and 5'-GGGCGCGGCGGGCGCGCCCAG
GGACTTACCACGAGCGCGCAGCACAGCAA-3'. The reaction was done in a final volume of $25 \mu \mathrm{L}$ that included $1 \mathrm{ng}$ of genomic DNA, $200 \mu \mathrm{mol}$ of dNTP mixture/L, $0.2 \mu \mathrm{mol}$ of each primer/L, $2 \mathrm{GC}$ buffer and $1 \mathrm{U}$ of TaKaRa LA Taq DNA polymerase (TaKaRa Biomedicals, Dalian, Liaoning, China). The PCR was done in a 2720 thermocycler (Applied Biosystems, Foster City, CA, USA) with an initial denaturation at $95^{\circ} \mathrm{C}$ for $5 \mathrm{~min}$, followed by 35 cycles of denaturation at $94{ }^{\circ} \mathrm{C}$ for $30 \mathrm{~s}$, annealing at $62{ }^{\circ} \mathrm{C}$ for $30 \mathrm{~s}$ and extension at $72{ }^{\circ} \mathrm{C}$ for $30 \mathrm{~s}$, with a final extension at $72{ }^{\circ} \mathrm{C}$ for $5 \mathrm{~min}$. The PCR products were digested with HincII restriction endonuclease (Fermentas, Burlington, $\mathrm{ON}$, Canada) at $37^{\circ} \mathrm{C}$ for $16 \mathrm{~h}$ and digestion products were separated on $2.5 \%$ agarose gels containing ethidium bromide. The $570 \mathrm{bp} \mathrm{PCR}$ product is cleaved into $288 \mathrm{bp}$ and $282 \mathrm{bp}$ fragments only in the presence of a $\mathrm{C}$ nucleotide at position 950. The PCR primers for T245G (271 bp fragment) were 5'-CGAACCCTAGAGCAAAGTGC-3' and 5'-TGTCTGATTGGCCCTAAAGC-3'. PCR was done as described above except that the annealing temperature was $56{ }^{\circ} \mathrm{C}$. The PCR products were digested with Hinfl restriction endonuclease (Fermentas) and separated on 3\% agarose gels containing ethidium bromide. In the presence of a T nucleotide at position 245 , the $271 \mathrm{bp}$ PCR product was cleaved into $202 \mathrm{bp}$ and $69 \mathrm{bp}$ fragments. Genotyping of the G1181C OPG exon 1 polymorphism was done using a mis-matched oligonucleotide approach. A 570 bp fragment was amplified with the primers 5'-TGCGTCCGGA TCTTGGCTGGATCGG-3' and 5'-GGGCGCGGCGGG CGCGCCCAGGGACTTACCACGAGCGCGCAGCAC AGCTA-3', the latter containing a $T$ instead of an A nucleotide two bases before the 3 ' end; this position corresponds to the third base of codon 3 that encodes lysine in exon 1 of the $O P G$ gene and the substitution introduces an artificial $X s p \mathrm{I}$ restriction site in the presence of the mutant allele. PCR was done as described above and the PCR products were digested with $X s p$ I restriction endonuclease (Fermentas) for $16 \mathrm{~h}$ and subsequently separated on $3 \%$ agarose gels containing ethidium bromide. In the presence of a $\mathrm{C}$ nucleotide at position 1,181, the $570 \mathrm{bp}$ PCR product was cleaved into $522 \mathrm{bp}$ and $48 \mathrm{bp}$ fragments. To independently validate the PCR-RFLP approach, we analyzed 49 randomly selected DNA samples ( $10 \%$ of the total samples) by direct sequencing and by PCR-RFLP; the results obtained with these two approaches were identical, indicating that the PCR-RFLP method was reliable.

\section{Statistical analysis}

Chi-square tests and $t$-tests were used to compare proportions and means of baseline characteristics between CVD and control subjects. Logistic regression was used to estimate the odd ratios (ORs) and 95\% CIs for CVD risk, after adjusting for age, sex, body mass index (BMI), hypercholesterolemia, smoking and hypertension. Hardy-Weinberg equilibrium was assessed with the Chi-square test or 
Fisher's exact test, as appropriate. Linkage disequilibrium was calculated using the software Haploview 4.1 for all pairwise single nucleotide polymorphism (SNP) combinations. All data analyses were done with SPSS 13.0 software (SPSS Inc., Chicago, IL, USA) for Windows (Microsoft Corp., Redmond, WA, USA). A value of $\mathrm{p}<0.05$ indicated significance and all statistical tests were two sided.

\section{Results}

The demographic and clinical data for the type 2 diabetic subjects with and without CVD are shown in Table 1. Univariate comparisons revealed no significant differences between the groups in terms of sex, age, BMI, HbA1c, hypertension and hypercholesterolemia. In contrast, there were significantly more $(p=0.02)$ smokers among diabetic patients with CVD than among those without CVD.

Table 2 shows the genotypic distribution of the T245C, T950C and G1181C gene polymorphisms. The genotype frequencies for all three polymorphisms were in Hardy-Weinberg equilibrium $(p>0.05)$ in the CVD and control subjects. Analysis with Haploview 4.0 revealed no linkage disequilibrium for any pair-wise combination among the three selected SNPs. Of the 178 patients with
CVD, the genotype distributions of the T245G and G1181C gene polymorphisms were not significantly different from those observed in the 312 subjects without CVD. Similarly, the minor allelic frequency (MAF) of the $\mathrm{T} 245 \mathrm{G}$ and G1181C gene polymorphisms were 0.11 and 0.34 in patients with CVD, which was not significantly different from that in subjects without CVD $(p=0.88$ and $p=0.73$, respectively). In contrast, there was a positive association between the T950C gene polymorphism and CVD in type 2 diabetic patients $(p=0.04$ for genotype and $p=0.02$ for allele, respectively). Based on this finding, we used unconditional logistic regression analysis to evaluate whether these gene variations were independent variables associated with CVD in type 2 diabetic patients. After adjusting for relevant confounding variables (age, sex, BMI, hypercholesterolemia, smoking and hypertension), the $\mathrm{C}$ allele of the T950C polymorphism was found to be independently associated with the risk of CVD in type 2 diabetic patients in the additive model $(\mathrm{OR}=1.38,95 \% \mathrm{CI} 1.07-1.80, \mathrm{p}=0.01)$. However, there was no significant association for the $\mathrm{T} 245 \mathrm{G}$ and G1181C gene polymorphisms in the additive model $(\mathrm{OR}=0.96,95 \%$ CI $0.64-1.45, \mathrm{p}=0.79$ and $\mathrm{OR}=1.06$, $95 \%$ CI $0.81-1.39, \mathrm{p}=0.65$, respectively). After adjusting for relevant confounding variables, none of the three poly-

Table 1 - Demographic data for type 2 diabetic patients with and without CVD.

\begin{tabular}{lccc}
\hline Variables & Control subjects $(n=312)$ & CVD subjects $(n=178)$ & p value \\
\hline Male $(\%)$ & $195(62.5)$ & $114(64.0)$ & 0.87 \\
Age $($ years $)$ & $57.2+9.5$ & $58.3+9.8$ & 0.83 \\
BMI $\left(\mathrm{kg} / \mathrm{m}^{2}\right)$ & $24.9+3.5$ & $25.2+3.1$ & 0.96 \\
HbA1c $(\%)$ & $6.6+1.6$ & $6.8+1.8$ & 0.88 \\
Diabetes $>10$ years $n(\%)$ & $194(62.2)$ & $109(61.2)$ & 0.92 \\
Diabetes $<10$ years $n(\%)$ & $118(37.8)$ & $69(39.8)$ & 0.89 \\
Smoking $n(\%)$ & $119(38.1)$ & $100(56.2)$ & 0.02 \\
Hypertension $n(\%)$ & $177(56.7)$ & $122(68.5)$ & 0.21 \\
Hypercholesterolemia $n(\%)$ & $130(41.7)$ & $98(55.1)$ & 0.09 \\
\hline
\end{tabular}

Data are the mean + standard deviation or \% unless otherwise indicated; BMI, body mass index; HbA1c, hemoglobin A1c.

Table 2 - Association between variants of the $O P G$ gene and CVD in patients with type 2 diabetes.

\begin{tabular}{|c|c|c|c|c|c|c|c|c|c|}
\hline \multirow[b]{2}{*}{ SNPs $(M>m)$} & \multirow[b]{2}{*}{ Population } & \multirow{2}{*}{$\begin{array}{c}\mathrm{MM} \\
N(\%)\end{array}$} & \multirow{2}{*}{$\begin{array}{c}\mathrm{Mm} \\
N(\%)\end{array}$} & \multirow{2}{*}{$\begin{array}{c}\mathrm{mm} \\
N(\%)\end{array}$} & \multirow[b]{2}{*}{$P_{\text {genotype }}$} & \multirow[b]{2}{*}{ MAF } & \multirow[b]{2}{*}{$P_{\text {allele }}$} & \multicolumn{2}{|c|}{ Additive model } \\
\hline & & & & & & & & OR $(95 \% \mathrm{CI})$ & $P$ \\
\hline $\mathrm{T} 245 \mathrm{G}(\mathrm{T}>\mathrm{G})$ & Control & $247(79.2)$ & $58(18.6)$ & $7(2.2)$ & & 0.12 & & & \\
\hline (rs3134069) & CVD & $142(79.7)$ & $32(18.0)$ & $4(2.3)$ & 0.98 & 0.11 & 0.88 & $0.96(0.641 .45)$ & 0.79 \\
\hline $\mathrm{T} 950 \mathrm{C}(\mathrm{T}>\mathrm{C})$ & Control & $108(34.6)$ & $152(48.7)$ & $52(16.7)$ & & 0.41 & & & \\
\hline (rs2073617) & CVD & $49(27.5)$ & $84(47.2)$ & $45(25.3)$ & 0.04 & 0.49 & 0.02 & $1.38(1.071 .80)$ & 0.01 \\
\hline $\mathrm{G} 1181 \mathrm{C}(\mathrm{G}>\mathrm{C})$ & Control & $141(45.2)$ & $135(43.3)$ & $36(11.5)$ & & 0.32 & & & \\
\hline (rs2073618) & CVD & $81(45.5)$ & $72(40.4)$ & $25(14.1)$ & 0.67 & 0.34 & 0.73 & $1.06\left(\begin{array}{lll}0.81 & 1.39\end{array}\right)$ & 0.65 \\
\hline
\end{tabular}

$P_{\text {genotype }}$ and $P_{\text {allele }}$ were calculated using the two-tailed Chi-square test or Fisher's exact test. Odds ratios (OR, with 95\% confidence interval) were computed using additive genetic models with multivariate unconditional logistic regression analysis adjusted for covariance. M, major allele; m, minor allele; MAF, minor allele frequency; SNP, single-nucleotide polymorphism. 
morphisms was associated with CVD in type 2 diabetic patients in the recessive or dominant model (all $p$ values $>0.05$ ).

\section{Discussion}

Osteoprotegerin $(O P G)$, a key factor in bone remodeling, is a member of the tumor necrosis factor (TNF) receptor family and a decoy receptor for the receptor activator of nuclear factor- $\mathrm{KB}$ ligand (RANKL) and TNF-related apoptosis inducing ligand (TRAIL). In addition to its role in the skeletal system, $O P G$ may have a role in vascular disease and has been implicated in human atherogenesis (Simonet et al., 1997; Emery et al., 1998; Browner et al., 2001). Previous studies had found serum $O P G$ levels to be positively correlated with the presence and severity of CVD (Jono et al., 2002; Schoppet et al., 2003). Clinical studies have shown that high serum $O P G$ levels are an independent risk factor for progressive atherosclerosis and cardiovascular diseases (Kiechl et al., 2004; Oh et al., 2005). For type 2 diabetic patients in particular, Avignon et al. (2005) reported an independent association between $O P G$ levels and asymptomatic coronary artery disease. $O P G$ gene polymorphisms have been associated with osteoporosis and vascular impairment (Hofbauer and Schoppet, 2002). Furthermore, subjects with a $\mathrm{C}$ allele in the promoter region at position 950 (TC and $\mathrm{CC}$ ) have significantly higher circulating $O P G$ serum levels, and genetic variations in the $O P G$ gene confer an increased risk of CVD and carotid plaque vulnerability in Caucasians (Soufi et al., 2004; Ohmori et al., 2006; Straface et al., 2011). However, Rhee et al. (2006) observed that polymorphisms in the promoter region of the $O P G$ gene were not associated with aortic calcification or coronary artery disease in Koreans. Given this background, the aim of this study was to investigate the possible association between genetic variations in the $O P G$ gene and the risk of CVD in type 2 diabetic patients.

This study is the first to show that the $\mathrm{C}$ allele of the T950C (rs2073617) polymorphism in the $O P G$ gene is significantly and independently associated with an increased risk of CVD in type 2 diabetic patients. This finding agrees with previous reports (Soufi et al., 2004; Ohmori et al., 2006). The T950C polymorphism is located 129 bp upstream from the TATA box, 13 bp downstream from an activating protein 2 binding site and $32 \mathrm{bp}$ upstream from a specificity protein 1 binding site. The biological significance of the association observed here is related to the fact that gene variants are functionally important. Previous studies have shown that the $\mathrm{C}$ allele of the T950C (rs2073617) polymorphism in the $O P G$ gene is significantly and independently associated with increased serum osteoprotegerin levels (Hofbauer and Schoppet, 2002; Straface et al., 2011). Interestingly, Biscetti et al. (2012) also showed that polymorphisms in the $O P G$ gene were associ- ated with increased risk of ischemic stroke in diabetic patients. These findings further support that conclusion that osteoprotegerin is a risk factor for progressive atherosclerosis and cardiovascular disease not only in the general population but also in type 2 diabetic patients. This conclusion is consistent with the concept that the individual chances of presenting an atherosclerotic-related disease may be affected by a susceptibility profile that is genetically defined (Brito et al., 2009; Ding and Kullo, 2009; Mollsten et al., 2009). These data further suggest a role for $O P G$ as a reliable biomarker in cardiac and vascular disease. Although the mechanisms linking $O P G$ and vascular disease require further study, the association between $O P G$ and CVD in type 2 diabetic patients shown here requires further investigation to clarify the possible role of OPG as a biomarker for identifying patients with, or at risk of, cardiovascular events.

This study has several limitations. First, the sample size in this study was relatively small and could yield a false positive result. In addition, the relatively small sample size and rare frequency of the $\mathrm{T} 245 \mathrm{G}$ polymorphism may have resulted in insufficient statistical power to detect a positive association. Our findings need to be confirmed in larger samples and in ethnically different groups. Second, this was a case-control study. Consequently, recruitment and survival bias cannot be excluded, particularly in the control population in which the possibility that some of the controls might develop cardiovascular disease in the future could not be eliminated. Third, this study was restricted to Han Chinese in order to avoid the possible confounding effect of race. For other ethnic groups or races, other genetic markers may be more effective in detecting the predisposing effect of the loci described here. The choice of appropriate markers requires knowledge of the differences in linkage disequilibrium patterns among races.

In summary, osteoprotegerin gene polymorphisms associated with CVD in the general population were also associated with CVD in diabetic subjects. Although diabetic and non-diabetic individuals showed similarities in their genetic susceptibility to CVD, diabetic patients had certain peculiarities in their genetic architecture that influenced their susceptibility to CVD.

\section{Acknowledgments}

The authors thank all the participants of the study.

\section{References}

Alberti KG and Zimmet PZ (1998) Definition, diagnosis and classification of diabetes mellitus and its complications. Part 1: Diagnosis and classification of diabetes mellitus provisional report of a WHO consultation. Diabet Med 15:539-553.

Avignon A, Sultan A, Piot C, Elaerts S, Cristol JP and Dupuy AM (2005) Osteoprotegerin is associated with silent coronary artery disease in high-risk but asymptomatic type 2 diabetic patients. Diabetes Care 28:2176-2180. 
Biscetti F, Straface G, Giovannini S, Santoliquido A, Angelini F, Santoro L, Porreca CF, Pecorini G, Ghirlanda G and Flex A (2012) Association between TNFRSF11B gene polymorphisms and history of ischemic stroke in Italian diabetic patients. Hum Genet 132:49-55.

Brito EC, Vimaleswaran KS, Brage S, Andersen LB, Sardinha LB, Wareham NJ, Ekelund U, Loos RJ and Franks PW (2009) PPARGC1A sequence variation and cardiovascular risk-factor levels: A study of the main genetic effects and gene $\mathrm{x}$ environment interactions in children from the European Youth Heart Study. Diabetologia 52:609-613.

Browner WS, Lui LY and Cummings SR (2001) Associations of serum osteoprotegerin levels with diabetes, stroke, bone density, fractures, and mortality in elderly women. J Clin Endocrinol Metab 86:631-637.

Chen L, Magliano DJ and Zimmet PZ (2011) The worldwide epidemiology of type 2 diabetes mellitus - Present and future perspectives. Nat Rev Endocrinol 8:228-236.

Collin-Osdoby P (2004) Regulation of vascular calcification by osteoclast regulatory factors RANKL and osteoprotegerin. Circ Res 95:1046-1057.

Crisafulli A, Micari A, Altavilla D, Saporito F, Sardella A, Passaniti M, Raffa S, D’Anneo G, Luca F, Mioni C, et al. (2005) Serum levels of osteoprotegerin and RANKL in patients with ST elevation acute myocardial infarction. Clin Sci (Lond) 109:389-395.

Ding K and Kullo IJ (2009) Evolutionary genetics of coronary heart disease. Circulation 119:459-467.

Emery JG, McDonnell P, Burke MB, Deen KC, Lyn S, Silverman C, Dul E, Appelbaum ER, Eichman C, DiPrinzio R, et al. (1998) Osteoprotegerin is a receptor for the cytotoxic ligand TRAIL. J Biol Chem 273:14363-14367.

Golledge J, McCann M, Mangan S, Lam A and Karan M (2004) Osteoprotegerin and osteopontin are expressed at high concentrations within symptomatic carotid atherosclerosis. Stroke 35:1636-1641.

Goranova-Marinova V, Goranov S, Pavlov P and Tzvetkova T (2007) Serum levels of OPG, RANKL and RANKL/OPG ratio in newly-diagnosed patients with multiple myeloma. Clinical correlations. Haematologica 92:1000-1001.

Hofbauer LC and Schoppet M (2002) Osteoprotegerin gene polymorphism and the risk of osteoporosis and vascular disease. J Clin Endocrinol Metab 87:4078-4079.

Jono S, Ikari Y, Shioi A, Mori K, Miki T, Hara K and Nishizawa Y (2002) Serum osteoprotegerin levels are associated with the presence and severity of coronary artery disease. Circulation 106:1192-1194.

Kadoglou NP, Gerasimidis T, Golemati S, Kapelouzou A, Karayannacos PE and Liapis CD (2008) The relationship between serum levels of vascular calcification inhibitors and carotid plaque vulnerability. J Vasc Surg 47:55-62.

Kiechl S, Schett G, Wenning G, Redlich K, Oberhollenzer M, Mayr A, Santer P, Smolen J, Poewe W and Willeit J (2004) Osteoprotegerin is a risk factor for progressive atherosclerosis and cardiovascular disease. Circulation 109:2175-2180.

Lusis AJ, Mar R and Pajukanta P (2004) Genetics of atherosclerosis. Annu Rev Genomics Hum Genet 5:189-218.

Mitka M (2009) Hemoglobin A1c poised to become preferred test for diagnosing diabetes. J Am Med Assoc 301:1528.

Mollsten A, Jorsal A, Lajer M, Vionnet N and Tarnow L (2009) The V16A polymorphism in SOD2 is associated with in- creased risk of diabetic nephropathy and cardiovascular disease in type 1 diabetes. Diabetologia 52:2590-2593.

Oh ES, Rhee EJ, Oh KW, Lee WY, Baek KH, Yoon KH, Kang MI, Yun EJ, Park CY, Choi MG, et al. (2005) Circulating osteoprotegerin levels are associated with age, waist-to-hip ratio, serum total cholesterol, and low-density lipoprotein cholesterol levels in healthy Korean women. Metabolism 54:49-54.

Ohmori R, Momiyama Y, Taniguchi H, Tanaka N, Kato R, Nakamura H, Ohsuzu F, Nagano M and Egashira T (2006) Association between osteoprotegerin gene polymorphism and coronary artery disease in Japanese men. Atherosclerosis 187:215-217.

Pitocco D, Zelano G, Gioffre G, Di Stasio E, Zaccardi F, Martini F, Musella T, Scavone G, Galli M, Caputo S, et al. (2009) Association between osteoprotegerin G1181C and T245G polymorphisms and diabetic charcot neuroarthropathy: A case-control study. Diabetes Care 32:1694-1697.

Puri R, Kataoka Y, Uno K and Nicholls SJ (2012) The distinctive nature of atherosclerotic vascular disease in diabetes: Pathophysiological and morphological insights. Curr Diab Rep 12:280-285.

Rhee EJ, Oh KW, Jung CH, Lee WY, Oh ES, Yun EJ, Baek KH, Kang MI and Kim SW (2006) The relationship between four single nucleotide polymorphisms in the promoter region of the osteoprotegerin gene and aortic calcification or coronary artery disease in Koreans. Clin Endocrinol 64:689-697.

Sandberg WJ, Yndestad A, Oie E, Smith C, Ueland T, Ovchinnikova O, Robertson AK, Muller F, Semb AG, Scholz H, et al. (2006) Enhanced T-cell expression of RANK ligand in acute coronary syndrome: Possible role in plaque destabilization. Arterioscler Thromb Vasc Biol 26:857-863.

Schoppet M, Sattler AM, Schaefer JR, Herzum M, Maisch B and Hofbauer LC (2003) Increased osteoprotegerin serum levels in men with coronary artery disease. J Clin Endocrinol Metab 88:1024-1028.

Simonet WS, Lacey DL, Dunstan CR, Kelley M, Chang MS, Luthy R, Nguyen HQ, Wooden S, Bennett L, Boone T, et al. (1997) Osteoprotegerin: A novel secreted protein involved in the regulation of bone density. Cell 89:309-319.

Song TJ, Kim J, Yang SH, Park JH, Lee HS, Nam CM, Lee OH, Kim YD, Nam HS and Heo JH (2012) Association of plasma osteoprotegerin levels with stroke severity and functional outcome in acute ischaemic stroke patients. Biomarkers 17:738-744.

Soufi M, Schoppet M, Sattler AM, Herzum M, Maisch B, Hofbauer LC and Schaefer JR (2004) Osteoprotegerin gene polymorphisms in men with coronary artery disease. J Clin Endocrinol Metab 89:3764-3768.

Straface G, Biscetti F, Pitocco D, Bertoletti G, Misuraca M, Vincenzoni C, Snider F, Arena V, Stigliano E, Angelini F, et al. (2011) Assessment of the genetic effects of polymorphisms in the osteoprotegerin gene, TNFRSF11B, on serum osteoprotegerin levels and carotid plaque vulnerability. Stroke 42:3022-3028.

Styrkarsdottir U, Halldorsson BV, Gretarsdottir S, Gudbjartsson DF, Walters GB, Ingvarsson T, Jonsdottir T, Saemundsdottir J, Center JR, Nguyen TV, et al. (2008) Multiple genetic loci for bone mineral density and fractures. N Engl $\mathrm{J}$ Med 358:2355-2365. 
Turk N, Cukovic-Cavka S, Korsic M, Turk Z and Vucelic B (2009) Proinflammatory cytokines and receptor activator of nuclear factor $\kappa \mathrm{B}$-ligand/osteoprotegerin associated with bone deterioration in patients with Crohn's disease. Eur J Gastroenterol Hepatol 21:159-166.

Ueland T, Yndestad A, Oie E, Florholmen G, Halvorsen B, Froland SS, Simonsen S, Christensen G, Gullestad L and Aukrust P (2005) Dysregulated osteoprotegerin/RANK ligand/RANK axis in clinical and experimental heart failure. Circulation 111:2461-2468.

Wijeysundera HC, Machado M, Farahati F, Wang X, Wittemen W, van der Velde G, Tu JV, Lee DS, Goodman SG, Petrella
$\mathrm{R}$, et al. (2010) Association of temporal trends in risk factors and treatment uptake with coronary artery disease mortality 1994-2005. JAMA 303:1841-1847.

Ziegler S, Kudlacek S, Luger A and Minar E (2005) Osteoprotegerin plasma concentrations correlate with severity of peripheral artery disease. Atherosclerosis 182:175-180.

Associate Editor: Mara H. Hutz

License information: This is an open-access article distributed under the terms of the Creative Commons Attribution License, which permits unrestricted use, distribution, and reproduction in any medium, provided the original work is properly cited 